\title{
A CASE OF EXTERNAL OPHTHALMOMYIASIS IN SEMI URBAN AREA IN BANGALORE
}

Nithisha T. M1, Vijay Kumar Srivastava², Nanda Shivkumar³, Kerheho Kera ${ }^{4}$, Sangeetha S5

\section{HOW TO CITE THIS ARTICLE:}

Nithisha T. M, Vijay Kumar Srivastava, Nanda Shivkumar, Kerheho Kera, Sangeetha S. "A Case of External Ophthalmomyiasis in Semi Urban Area in Bangalore". Journal of Evolution of Medical and Dental Sciences 2014; Vol. 3, Issue 56, October 27; Page: 12826-12828, DOI: 10.14260/jemds/2014/3702

ABSTRACT: Infestation and occurrence of diseases of living tissue or organs by fly larvae is called myiasis. Depending on the region infestation involve, Blow fly myiasis, Cutaneous myiasis, Gastrointestinal myiasis etc. Ophthalmic myiasis has been reported from various part of the world especially among the farmers. Here we are presenting a case of external ophthalmomyiasis caused by larvae of sheep nasal botfly. Similar cases are been reported in the rural areas but it is rare in the semi urban and urban areas like Bangalore. 1 larva was removed from the left eye of the patient after which the inflammation came down within $30 \mathrm{~min}$.

KEYWORDS: Ophthalmomyiasis, Sheep nasal botfly, Semi urban, Bangalore.

INTRODUCTION: Ocular myiasis is caused by larvae of a fly such as sheep nasal botfly ${ }^{[1]}$ as was in our case. Cases of ophthalmic myiasis externa by Oestrus Ovis have been reported from different part of the world [2-4] including India. But most of the occurrence is typically found in rural part India. The present case thus create an awareness to both the community and the ophthalmologist regarding detection, diagnosis and management of ocular myiasis.

CASE REPORT: A female patient of about 28 years of age presented to Out Patient Department of ophthalmology on 13/9/14 with the complaints of excessive watering, foreign body sensation, and sharp pain in the left eye. She gives history that two days earlier something went into her left eye while working in the garden. On the next day she started having burning sensation in the eye which was followed by rest of the symptoms.

On examination her distant visual acuity was $6 / 6$ both eye, upper left eyelid was mildly edematous with superficial conjunctival congestion, profuse lacrimation, extraocular movements were full, no preauricular lymphadenopathy. Under slit lamp examination there was a translucent tiny worm (1-2mm long) crawling over the bulbar conjunctiva. The worm was avoiding the slit lamp light and moving toward the superior fornix from the superior aspect of bulbar conjunctiva. Pupil was regular and reactive with normal anterior chamber.

Irrigation with normal saline was unsuccessful in washing larva out as it grabbed the conjunctiva firmly with oral and body hooks. Topical anesthesia (auracaine 3\%) was instilled in the eye and the larva was removed with cotton swab stick under magnification and sent for identification to the department of microbiology. Other routine ophthalmological examination was done along with mydriasis and no evidence of ophthalmomyiasis interna was found. Topical antihistaminic and antibiotic drops were prescribed. Repeat examination of anterior segment and fundus was normal after a week. 
The organism was later identified as the first stage of Oestrus Ovis (Sheep nasal botfly) on the basis of their spindle shaped skeleton with a pair of oral hooks and tufts of numerous brown hooks on the anterior margin of each body segment. [Figure].

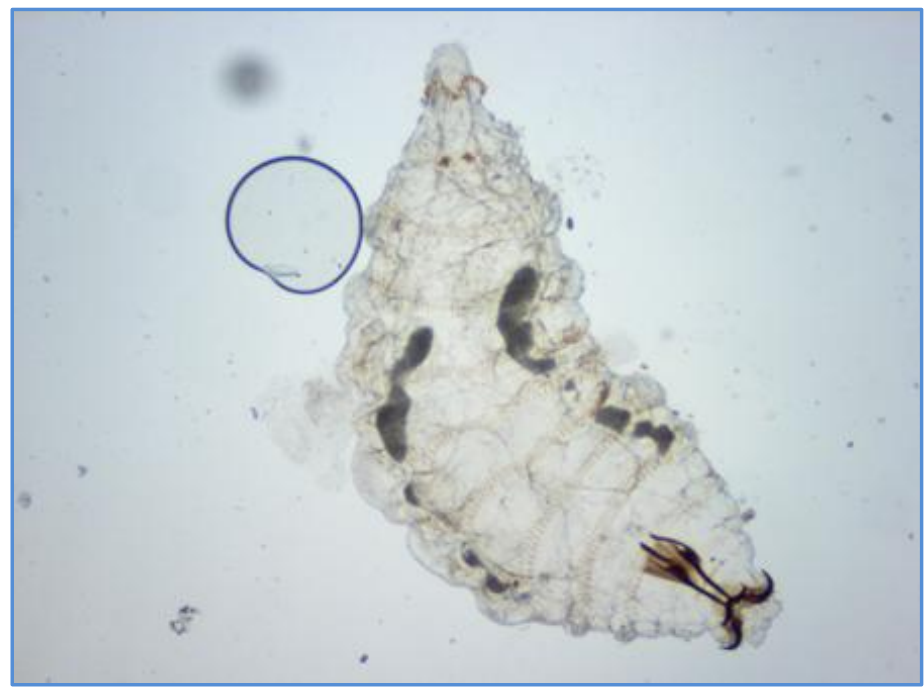

DISCUSSION: Ophthalmic myiasis manifestation can occur in two form, ophthalmomyiasis externa and ophthlmomyiasis interna.[5] Various species of flies causing to provoke ophthalmomyiasis are Oestrus Ovis, Latrin Fly (Fannia), House fly and Cattle botfly.[6] Oestrus Ovis is the most common cause of Ophthalmic myiasis in man. ${ }^{[4]}$ The history of ophthalmic myiasis in human was dated back to 1947 by James.[7] The female flies dash at their victims and deposit freshly hatched larvae in the nares, lids, mouth and conjunctiva. ${ }^{[8]}$ The usual host are sheep, cattle, horse and deer.

Man serves as an accidental host. Human ophthalmomyiasis occurs mainly in places where density of sheep is relatively low compared to human. ${ }^{[5]}$ Since our patient was residing in Bangalore, it highlights the need to create awareness among the ophthalmologists for the same condition in semi urban areas. Previous papers presenting ocular myiasis was predominantly from rural area in India where man lives in close contact with small ruminants (i.e. sheep and goats). ${ }^{[9]}$

Organism should be removed with sterile cotton swab stick or with forceps under magnification to prevent complication. External ophthalmomyiasis manifests as acute catarrhal conjunctivitis. [10] Therefore should be regarded as a benign condition and treated promptly to prevent serious complications such as corneal ulcer, iridocyclitis, and endophthalmitis.[11]

\section{REFERENCES:}

1. Amr ZS, Amr BA, Abo-Shehada MN. Ophthalmomyiasis externa caused by Oestrus ovis L. in the Ajloun area of northern Jordan. Ann Trop Med Parasitol. 1993; 87:259-262. [PubMed].

2. Victor R, Bhargva K. Ophthalmomyiasis in Oman: a case report and comments. Wilderness Environ Med. 1998; 9:32-35. [PubMed].

3. Minar J. A case of eye myiasis in man caused by first instar larvae of Oestrus ovis L (Diptera: Oestridae) in Iran. Folia Parasitol. (Praha) 1976; 23:283-84. [PubMed]. 
4. Grammer J, Erb C, Kamin G, Wild MR, Riedinger C, Kosmidis P, et al. Ophthalmomyiasis externa due to the sheep botfly Oestrus ovis in South-West Germany. Gev J Ophthalmol. 1995; 4:18895. [PubMed].

5. Zumpt, F. Ophthalmomyiasis in man, with special reference to the situation in southern Africa. S Afr Med J. 1963;37: 425-428. PubMed.

6. Mandell GL, Douglas RG, Bennett JE, Mandell Dolin R., Douglas, Bennett, Dolin. Principles and Practice of Infectious Disease. 5th. Philadelphia: Churchill Livingstone; 2000.

7. Patel SJ. Extraocular myiasis due to the larva of Oestrus ovis. East Afr Med J. 1975; 52:167-69. [PubMed].

8. Beaver PC, Jung RC, Cupp EW. Clinical Parasitology. 9th ed. Philadelphia, USA: Lea \& Febiger; 1984. pp. 680-695.

9. Sucilathangam G, Meenakshisundaram A, Hariramasubramanian S, Anandhi D, Palaniappan N, Anna T. External Ophthalmomyiasis Which Was Caused By Sheep Botfly (Oestrus Ovis) Larva: A Report Of 10 Cases. Journal of Clinical and Diagnostic Research [serial online] 2013 03[cited: 2014 Sep 25] 3539 - 542.

10. Mohsen M, Keramatalab H. External ophthalmomyiasis caused by sheep botfly (Oestrus ovis) larvae: a report of 8 cases. Arch Iran Med. 2004; 7:136-139.

11. Hunt EW Jr. Unusual case of ophthalmomyiasis interna posterior. Am J Ophthalmol. 1970; 70:978-980. [PubMed].

\section{AUTHORS:}

1. Nithisha T. M.

2. Vijay Kumar Srivastava

3. Nanda Shivkumar

4. Kerheho Kera

5. Sangeetha S.

\section{PARTICULARS OF CONTRIBUTORS:}

1. Associate Professor, Department of Ophthalmology, Rajarajeswari Medical College and Hospital, Bangalore.

2. Professor \& HOD, Department of Ophthalmology, Rajarajeswari Medical College and Hospital, Bangalore.

3. Senior Resident, Department of Ophthalmology, Rajarajeswari Medical College and Hospital, Bangalore.
4. Post Graduate, Department of Ophthalmology, Rajarajeswari Medical College and Hospital, Bangalore.

5. Professor \& HOD, Department of Microbiology, Rajarajeswari Medical College \& Hospital, Bangalore.

\section{NAME ADDRESS EMAIL ID OF THE CORRESPONDING AUTHOR:}

Dr. Kerheho Kera, \# C74, 21/2 Mile, Darogapathar Vill, Dimapur, Nagaland-797116. Email: kerol_dark@yahoo.co.in

Date of Submission: 10/10/2014.

Date of Peer Review: 11/10/2014.

Date of Acceptance: 22/10/2014.

Date of Publishing: 27/10/2014. 